\title{
Preliminary floristic analysis of the major biomes in southern Africa
}

\author{
G. E. GIBBS RUSSELL *
}

Keywords: biomes, Desert, Fynbos, Grassland, Karoo, Nama-Karoo, Savanna, species diversity, Succulent Karoo

\section{ABSTRACT}

Over 24000 plant taxa are known to occur in the southern African flora, which is extraordinarily rich on a species/area basis. Lists of species and infraspecific taxa recorded for the six major biomes. Fynbos. Savanna, Grassland, Nama-Karoo, Succulent Karoo and Desert, were obtained from the PRECIS specimen database. These lists were analysed by numbers of unique and shared species and infraspecific taxa, by differential occurrence and life forms of large genera, and by differential occurrence of families. Each biome is floristically distinct except Nama-Karoo. The biomes form two main groupings, those with winter rainfall and those with summer rainfall. Succulent Karoo is most similar to Fynbos and Nama-Karoo is most similar to Savanna.

\section{UITTREKSEL}

Dit is bekend dat meer as 24000 planttaksons in die suider-Afrikaanse flora voorkom, wat op 'n spesies/areagrondslag buitengewoon ryk is. Lyste van spesies en infraspesifieke taksons van die ses hoofbiome. Fynbos, Savanne. Grasveld, Nama-Karoo, Sukkulente Karoo en Woestyn, is vanaf die PRECIS-eksemplaardatabasis verkry. Hierdie lyste is ontleed in terme van unieke en gemeenskaplike spesies en infraspesifieke taksons, differensiële voorkoms en lewensvorme van groot genusse, en die differensiële voorkoms van families. Elke bioom behalwe Nama-Karoo, is floristies kenmerkend. Die biome vorm twee hoofgroeperings, dié met winterreënval en dié met somerreënval. Sukkulente Karoo toon die meeste ooreenkoms met Fynbos en Nama-Karoo toon die meeste ooreenkoms met Savanne.

\section{CONTENTS}

Introduction .213

Methods

214

Results and discussion............................... 216

Area, taxa and specimens.....................216

Comparison of biomes by numbers of species and infraspecific taxa .......................2.216

Sorenson's coefficients of similarity .............216

Percentages of unique and shared taxa .......... 217

Comparison of biomes by important families and large genera ............................ 217

Differential occurrence of important families 217

Centres of diversity of large genera ...........219

Life forms and centres of diversity of large genera

Floristic characteristics and relationships of the biomes

Fynbos.

Savanna .............................................221

Grassland ....................................... 221

Nama-Karoo .......................................... 221

Succulent Karoo .................................... 221

Desert ....................................... 221

Relationships ...................................... 222

Conclusions ............................................. 222

Acknowledgements ................................2222

References ....................................... 222

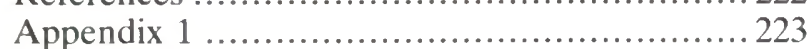

Appendix 2 ......................................... 225

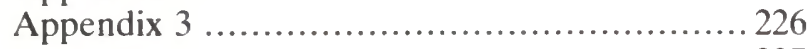

Appendix 4 ..................................... 227

* Botanical Research Institute, Private Bag X101, Pretoria 0001.

\section{INTRODUCTION}

The southern African flora is extremely speciesrich in terms of species/area ratios, with 0,0081 species $/ \mathrm{km}^{2}$ overall (Figure 1). This value is higher than those recorded for humid tropical floras such as Brazil $(0,0044)$ and Asia $(0,0041)$ (Gibbs Russell 1985b). The winter rainfall Cape Floral Kingdom is well known to be extremely species-rich (Goldblatt 1978). However, even when the Cape flora is excluded from calculation, the species/area ratio for the rest of the southern African flora $(0,0061)$ is still considerably higher than that of the humid tropics, and nearly twice that of Australia $(0,0032)$, which also includes both tropical and temperate areas.

These species/area ratios indicate in a superficial way that the remarkable species richness of the southern African flora is not restricted to the Cape Floral Kingdom. The aim of this study is to investigate the floristic richness of the major biomes and to explore floristic relationships between these biomes using distribution data for families, genera and species.

At the present time, the PRECIS (Pretoria National Herbarium Computerized Information System) specimen database is by far the most comprehensive source of information on the distribution of plant taxa in southern Africa. Although PRECIS has certain limitations (see Methods), this preliminary study forms a base against which more detailed studies of particular biomes can be put in context, and which will allow the generation of hypotheses to guide future studies. A re-evaluation should be done when more complete checklists, based on co-operative herbarium studies and intensive field work, have been compiled for all the biomes. 

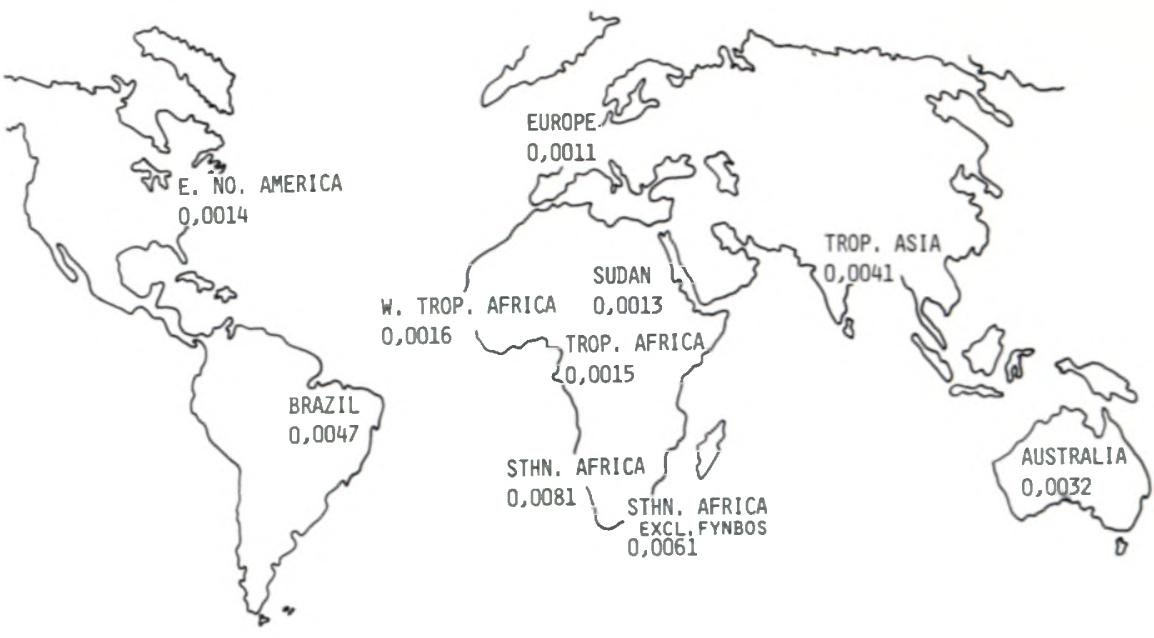

FIGURE 1. - Species/area ratios for large regions. The number of species and areas in $\mathrm{km}^{2}$ for each region follow Gibbs Russell (1985b).
METHODS

This study is based on checklists compiled from PRECIS for quarter degree latitude and longitude grids representing the major biomes for southern Africa. The biomes adopted were determined by superimposing five recent treatments of southern African vegetation using floristic, structural and environmental criteria (Werger 1978; Scheepers 1982 based on Acocks 1975; White 1983; Huntley 1984; Rutherford \& Westfall 1986). The resulting compos- ite map showed six major regions that were recognized as entities, even though none of the studies agreed on exact boundaries. Elimination of all areas of disagreement, and of areas smaller than a quarter degree, yielded the regions accepted as the core biomes for this investigation (Figure 2). Important environmental characteristics of the core biomes are shown in Table 1.

The lack of agreement between the treatments occurred at three levels: 1 , exact boundaries at quar-

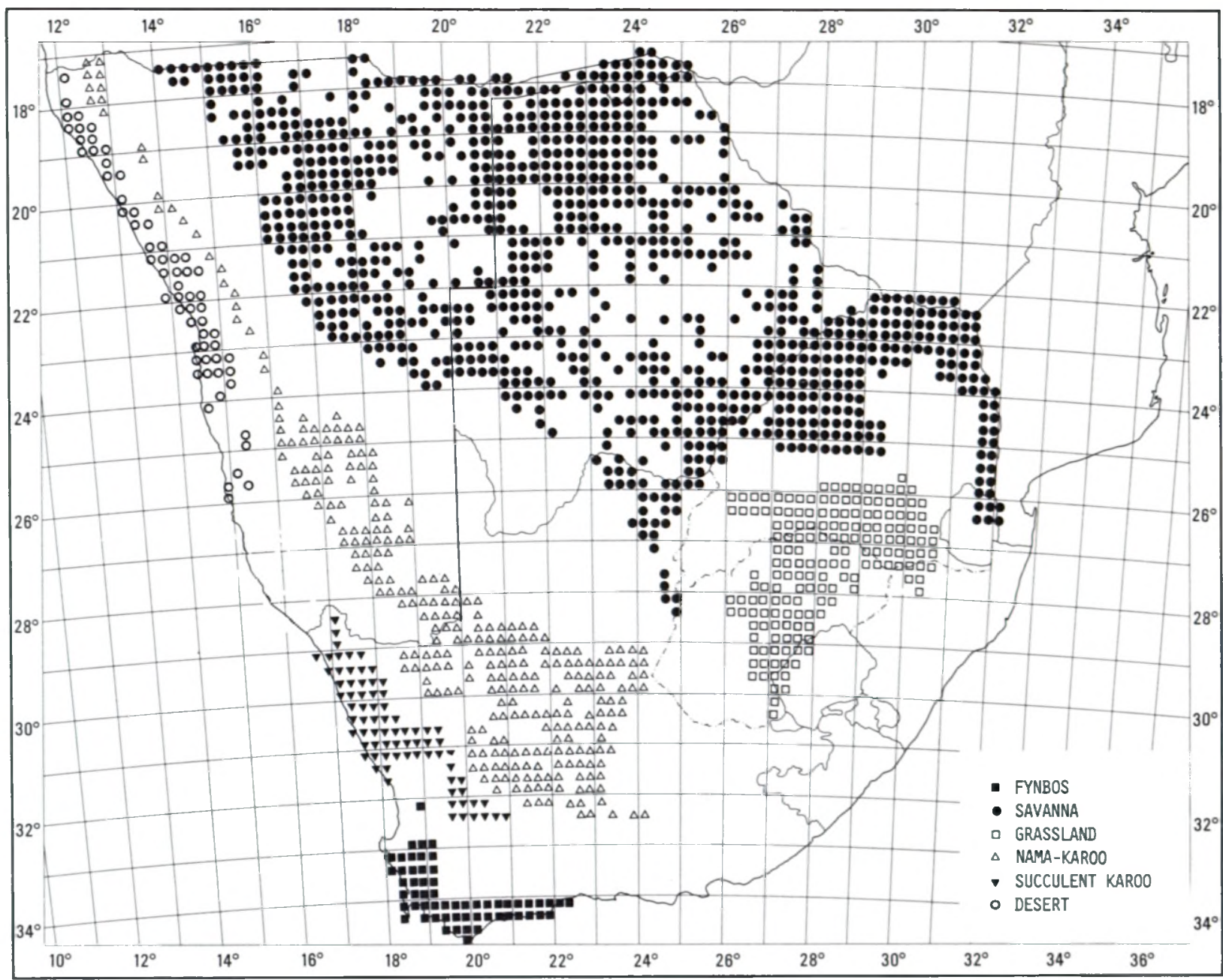

TS.0. Misc. 8091

$\mathrm{km} 100 \quad 0 \quad 100 \quad 200 \quad 300 \quad 400 \quad 500 \quad 600 \quad 700 \quad 800 \mathrm{~km}$

FIGURE 2. - Quarter degree grids searched in PRECIS for each biome. 
TABLE 1.-Characteristics of the biomes

\begin{tabular}{|c|c|c|c|c|}
\hline Biome & Rainfall amount* & Rainfall season* & Dominant life forms* & Structural characteristics \\
\hline Fynbos & $\begin{array}{l}\text { Mesic } \\
(210-3000 \mathrm{~mm})\end{array}$ & Winter & $\begin{array}{l}\text { Chamaephytes } \\
\text { Phanerophytes } \\
\text { Cryptophytes }\end{array}$ & $\begin{array}{l}\text { Evergreen sclerophyllous heathland and } \\
\text { shrubland }{ }^{\dagger}\end{array}$ \\
\hline Savanna & $\begin{array}{l}\text { Mesic } \\
\text { (above } 235 \mathrm{~mm} \text { ) }\end{array}$ & Summer & $\begin{array}{l}\text { Hemicryptophytes } \\
\text { Phanerophytes }\end{array}$ & Wooded $\mathrm{C}_{4}$ grasslands ${ }^{\dagger}$ \\
\hline Grassland & $\begin{array}{l}\text { Mesic } \\
(400-2000 \mathrm{~mm})\end{array}$ & Summer & Hemicryptophy tes & Grassland, woody plants absent or rare ${ }^{\dagger}$ \\
\hline Nama-Karoo & $\begin{array}{l}\text { Arid } \\
(100-520 \mathrm{~mm})\end{array}$ & $\begin{array}{l}\text { Summer } \\
\text { (to all year) }\end{array}$ & $\begin{array}{l}\text { Chamaephy tes } \\
\text { Hemicryp tophy tes }\end{array}$ & Dwarf and low open shrublands ${ }^{\dagger}$ \\
\hline Succulent Karoo & $\begin{array}{l}\text { Arid } \\
(20-290 \mathrm{~mm})\end{array}$ & $\begin{array}{l}\text { Winter } \\
\text { (to all year) }\end{array}$ & Chamaephytes & $\begin{array}{l}\text { Dwarf and low open succulent shrub- } \\
\text { lands }{ }^{\dagger}\end{array}$ \\
\hline Desert & $\begin{array}{l}\text { Arid } \\
(13-70 \mathrm{~mm})\end{array}$ & Summer & Therophy tes & Ephemeral, with many annuals \\
\hline
\end{tabular}

* Rutherford \& Westfall (1986)

† Huntley (1974)

ter degree scale; 2 , areas of transition between karroid and savanna regions; and 3 , areas of complicated vegetation relationships, such as the eastern Transvaal, Natal and the eastern Cape. The two 'karroid' biomes accepted here were recognized at the highest level of classification only by Rutherford \& Westfall (1986), on grounds of differences in dominant plant life form and environmental conditions. Their Succulent Karoo Biome roughly coincided with the Western Cape Domain of the KarooNamib Region defined by Werger (1978) at a secondary level of classification on phytochorological grounds. The other three vegetation studies treated the entire karroid vegetation as a single entity at the highest level. In this investigation, Succulent Karoo was separated from Nama-Karoo, and a secondary aim of the study was to examine the floristic relationship between them.

Besides the six core biomes adopted for this study, all the treatments recognized the high altitude vegetation of the Drakensberg, and the forests of the southern Cape. However, these small irregularly shaped areas were not accessible to computer search at the scale of quarter degree grid reference, and could therefore not be included.

The PRECIS specimen database records label information for \pm 610000 specimens in the National Herbarium (PRE). The overall operation and implementation of PRECIS have been reported several times (Gibbs Russell \& Gonsalves 1984; Gibbs Russell 1985a). More recently, new programming has allowed compilation from the database of checklists of plant species and infraspecific taxa from any combination of quarter degree grids. Several special programmes were written to compare the checklists by providing lists of unique taxa, lists of shared taxa, and a matrix of all taxa with the biomes from which they were recorded.

The total numbers of unique and shared taxa, obtained by employing these programmes, were used to calculate Sorenson's (1948) coefficients of similarity, and percentages of unique taxa and taxa shared between biomes. The ranking of families for each biome, the identification of widespread taxa, and the determination of centres of diversity for 'large' genera with 10 or more species and infraspecific taxa were obtained by manual searches of printout. A biome was considered to be a centre of diversity for a genus if it contained $50 \%$ or more of the taxa reported for the genus. In a few cases, slightly less than half (to $45 \%$ ) was accepted in biomes of low collecting intensity. Life forms follow the definitions of Raunkiaer (1934) as stated by Rutherford \& Westfall (1986), but with the inclusion of 'Succulent', and were determined from Dyer $(1975,1976)$ and herbarium specimens. At all stages of work, doubtful records encountered on PRECIS listings were checked in PRE.

An inherent weakness in the method used is the uneven collecting intensity for the different biomes. Gibbs Russell et al. (1984) showed that the collecting intensity represented in PRECIS for the eastern and southern mesic areas is far higher than for the western arid areas. Therefore, the checklists used here undoubtedly differ in completeness, and it must be emphasized that these results are preliminary. Table 2 illustrates the differences in collecting intensity between the biomes by comparing the specimens and the taxa per $\mathrm{km}^{2}$ as well as the specimens per taxon recorded in PRECIS for each biome. Although Fynbos, and to a lesser degree Grassland, appear to be better collected than the other biomes on a specimens $/ \mathrm{km}^{2}$ or taxa $/ \mathrm{km}^{2}$ basis, Savanna in fact exhibits more 'repeat' collections than either. However, it is apparent that mesic Fynbos, Savanna and Grassland are better collected than arid Nama-Karoo, Succulent Karoo and Desert.

PRECIS is known to have errors in about $7 \%$ of specimen identifications and quarter degree grid references. Until these errors can be corrected, an ongoing process in system management, results must be used with discretion. In this study, identifications directly from PRECIS are used only at the level of family and genus, while at the level of species and infraspecific taxa, only total numbers, and not identifications, are used unless the records were checked 
TABLE 2.-Collecting intensity reported from PRECIS for each biome. Area was determined from the number of quarter degree grids searched (and 'average' quarter degree covers $666 \mathrm{~km}^{2}$ )

\begin{tabular}{|c|c|c|c|c|c|c|}
\hline & No. specimens & No. $\operatorname{tax} a$ & Area $\left(\mathrm{km}^{2}\right)$ & Specimens $/ \mathrm{km}^{2}$ & $\mathrm{Taxa} / \mathrm{km}^{2}$ & Specimens/taxon \\
\hline Fynbos & 52650 & 7316 & 36628 & 1,36 & 0,19 & 7,2 \\
\hline Savanna & 50460 & 5788 & 632034 & 0,08 & 0,01 & 8,7 \\
\hline Grassland & 27685 & 3788 & 111888 & 0,25 & 0,03 & 7,3 \\
\hline Nama-Karoo & 7685 & 2147 & 198468 & 0,04 & 0,01 & 3,6 \\
\hline Succulent Karoo & 6484 & 2125 & 50616 & 0,13 & 0,04 & 3,1 \\
\hline Desert & 1334 & 497 & 41292 & 0,03 & 0,01 & 2,7 \\
\hline
\end{tabular}

in PRE. For the same reason, distribution is given only at biome level, and not to individual quarter degree grids.

Despite the limitations imposed by differences in collecting intensity and by the accuracy of individual PRECIS records, at the present time PRECIS is the most reliable and complete source of information about the distribution of taxa throughout the southern African flora. Publication of these preliminary results is therefore considered worthwhile.

Throughout the study, the number of species and infraspecific taxa, rather than species alone, were used in comparisons because of taxonomic uncertainty about the correct level of treatment for many of these entities, as explained in detail in Gibbs Russell (1985b). For the sake of brevity, the term 'taxa' in this context is used in place of the longer phrase 'species and infraspecific taxa'.

\section{RESULTS AND DISCUSSION}

\section{Area, taxa and specimens}

The area, taxa and specimens covered in this study are summarized in Table 3 . The five recent vegetation treatments used to determine the biomes for this study agreed on about $40 \%$ of the total area of southern Africa at a scale available for computer search. About $60 \%$ of all southern African taxa represented in PRECIS were reported from the area designated. Certain taxa were not included in the study for the following reasons: 1 , they are known only outside the areas of the core biomes; 2 , they are not represented in PRECIS; or 3, they are represented in PRECIS, but the distribution is not recorded as a quarter degree grid. Only about $25 \%$ of the specimens in PRECIS are reported in the study. This low figure results from the uneven collecting intensity in the National Herbarium mentioned above.

TABLE 3.- Total size of sample reported for all biomes

$\begin{array}{lc}\text { Number of specimens } & 146298 \\ \text { Out of } 610000 \text { in PRECIS } & 24 \% \\ \text { Out of } \pm 2000000 \text { in southern African herbaria } & 7 \% \\ & \\ \text { Number of taxa } & 14391 \\ \text { Out of } 24000 \text { in southern Africa } & 60 \%\end{array}$

Area covered (1611 quarter degree grids

@666 km² per quarter degree)

Out of $2573000 \mathrm{~km}^{2}$ for southern Africa

$1072926 \mathrm{~km}^{2}$ $42 \%$

\section{Comparison of biomes by numbers of species and infraspecific taxa}

Widely differing numbers of taxa have been recorded for the six biomes, and the differences in taxon numbers are not related to the area sampled (Table 2). Fynbos has the most taxa although it is the smallest in area. Savanna, which covers by far the largest area, has about 1500 fewer taxa than Fynbos. Similarly, Grassland has about 1700 more taxa than Nama-Karoo, although Nama-Karoo covers about twice the area of Grassland. Nama-Karoo and Succulent Karoo have similar numbers of taxa, but Nama-Karoo covers about four times the area of Succulent Karoo. The number of taxa recorded for Desert is extremely low even though its area is slightly larger than that of Fynbos.

The checklists for each biome were compared both by Sorenson's (1948) coefficient of similarity, and by percentage comparisons within each biome. Sorenson's coefficients give comparable values for checklists of different length. Low Sorenson's coefficients signify low similarity between lists of taxa, while higher values show a greater similarity. The percentage comparisons show the proportion of taxa within each biome that are unique and that are shared with other biomes.

\section{Sorenson's coefficients of similarity}

The Sorenson's coefficients of similarity between the six major biomes are shown in Figure 3. The values for the coefficients are generally low (30 or less), indicating that each biome has its own flora which is quite distinct from that of the others. The exception is the coefficient between Savanna and Grassland, which is considerably higher than any other.

For Savanna, the highest Sorenson's coefficients occur with Grassland and with Nama-Karoo, and the values are low (less than 20) for the other biomes. Grassland, which has the strongest similarity to Savanna, has very low Sorenson's coefficients with Desert and with Succulent Karoo, and somewhat higher values with Fynbos and Nama-Karoo. Desert has very low values with all biomes except NamaKaroo. Fynbos has low Sorenson's coefficients with all biomes except Succulent Karoo. Succulent Karoo and Nama-Karoo show opposite relationships. Excluding the Sorenson's coefficient between the two 'karroid' biomes, Succulent Karoo has its highest value with Fynbos, and very low values with Desert, 


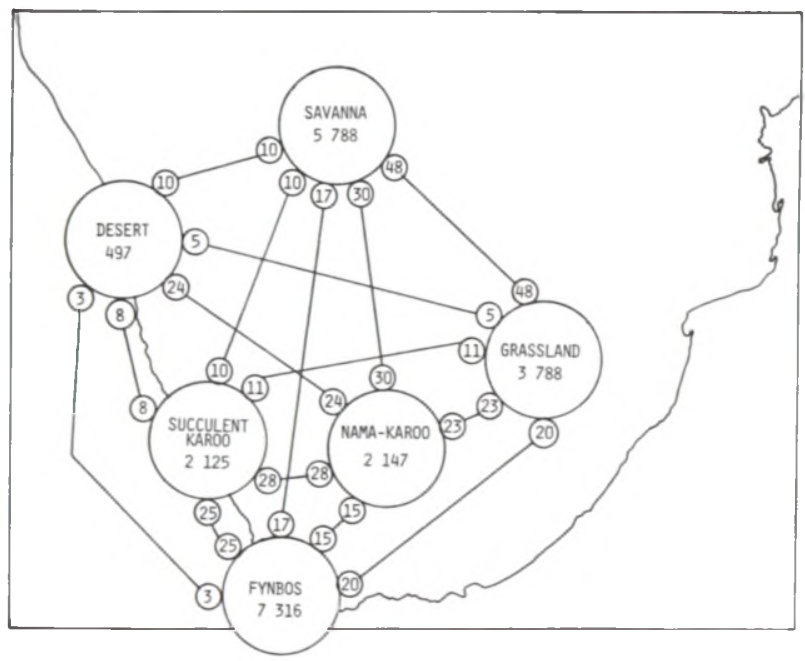

FIGURE 3. - Number of taxa and Sorenson's coefficients of similarity for the biomes. The number in each large circle is the number of species and infraspecific taxa reported for the biome. The number in each small circle is the Sorenson's coefficient of similarity between pairs of biomes.

Savanna and Grassland, whereas Nama-Karoo has its highest value with Savanna, high values with Desert and Grassland, and a low value with Fynbos.

\section{Percentages of unique and shared taxa}

The percentages of taxa unique to each biome and shared between biomes are shown in Figure 4 . The biomes vary greatly in percentages of unique taxa. Fynbos has the highest percentage (which is consistent with a value of $68 \%$ given by Bond \& Goldblatt (1984)), and Savanna is also well above the others. Grassland and Succulent Karoo are similar, and Desert and Nama-Karoo have similar and very low percentages of unique taxa.

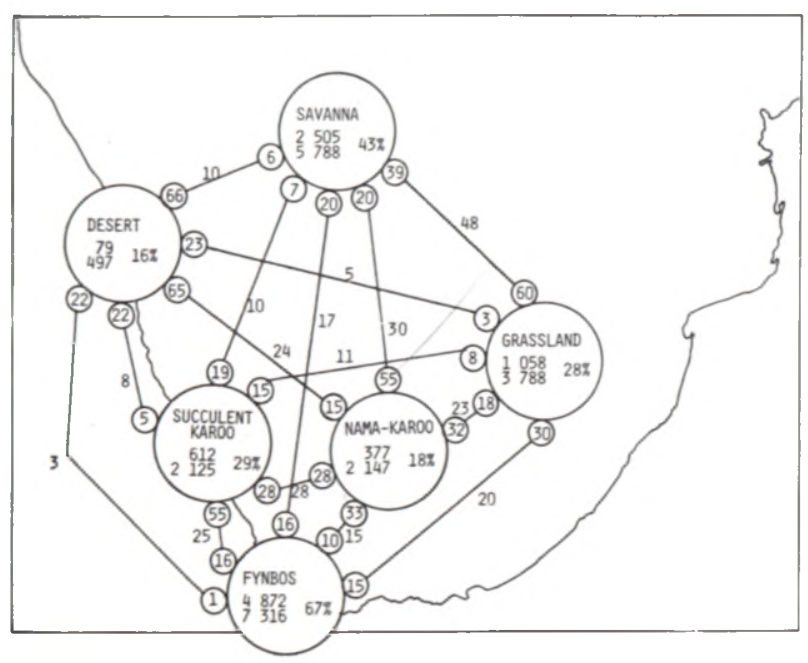

FIGURE 4. - Number and percentage of species and infraspecific taxa unique to and shared between biomes. In each large circle, the upper number is the number of unique taxa, the lower number is the total number of taxa for the biome, and the percentage is the percentage of taxa unique for the biome. The number in each small circle is the percentage of taxa shared between pairs of biomes, and the number on the line connecting a pair is the Sorenson's coefficient of similarity.
The percentage of taxa shared between the biomes amplifies the relationships shown by the Sorenson's coefficients. The few apparent contradictions result from comparing taxon lists of very different length: where one list is long and the other short, the percentage of shared taxa differs markedly from the Sorenson's values.

The close floristic relationships between Savanna and Grassland and Savanna and Nama-Karoo showr by the Sorenson's coefficients are borne out by the high percentage of Grassland and Nama-Karoo taxc that is shared with Savanna. Savanna itself shares most taxa with Grassland, shares the same percentage of its taxa with Nama-Karoo as with Fynbos, and shares a very low percentage of its taxa with Succulent Karoo and Desert. Grassland shares a very high percentage of its taxa with Savanna, and is similar to Savanna in that its lowest percentage of shared taxa is with Succulent Karoo and Desert, but Grassland shares a considerably higher percentage of taxa with Fynbos than with Nama-Karoo. Desert, which because of its small flora shows very low Sorenson's values with all biomes except Nama-Karoo, shares about the same very high percentage of its taxa with Savanna as with Nama-Karoo. Desert has a very low percentage of unique taxa, and shares more than $20 \%$ of its taxa with Grassland, with Succulent Karoo and with Fynbos. In contrast, Fynbos, which has a high percentage of unique taxa, does not share more than $20 \%$ of its taxa with any other biome. The close relationships of Succulent Karoo to Fynbos and of Nama-Karoo to Savanna, already indicated by Sorenson's coefficients, are borne out by the high percentage of Succulent Karoo taxa shared with Fynbos, and the high percentage of Nama-Karoo taxa shared with Savanna. Both of the 'karroid' biomes share the lowest percentage of taxa with Desert and an intermediate percentage with Grassland.

\section{Comparison of biomes by important families and large genera}

\section{Differential occurrence of important families}

Forty-six families comprise $1 \%$ or more of the taxa in at least one biome. In each biome there are between 22 and 28 families that comprise $1 \%$ or more of the taxa, and that together account for between 55 and $60 \%$ of the total number of taxa. Each of these families can be used to distinguish and/or link the biomes (Table 4).

In order to compare the biomes in this way, these important families are ranked for every biome by number of taxa from largest (rank of 1) to smallest (rank of 22 to 28). Ranking is necessary for comparison at family level because the biomes differ so greatly in number of taxa. A family well represented in a species-poor biome may in fact have fewer taxa in that biome than the same family has in a biome with a rich flora, even though the family is a negligible component of the more species-rich biome (Gibbs Russell 1975, 1985b). The families are ranked in three groups in the discussion: the largest families (1-3 in bold type in Table 4); the next rank (4-10 in italics in Table 4); and the lowest rank (from 
11 onwards in roman type in Table 4). The biomes are characterized by the presence, absence or difference in rank of certain large families, and the occurrence of some families can be linked to simple environmental parameters characteristic of certain combinations of biomes.

The seven plant families that comprise $1 \%$ or more of the taxa in all of the biomes are shown in Table 4a. Three families, Asteraceae, Poaceae and Fabaceae are the three largest in all biomes (with the exception of Poaceae in Succulent Karoo and Fynbos), and either Asteraceae or Poaceae is the largest family in all biomes. Asteraceae and not Poaceae is the largest family in Grassland.

The six biomes are briefly discussed in turn below:

Fynbos (Table $4 \mathrm{~b}$ ) is distinguished by eight families that are important in no other biome. Of these, Ericaceae is one of the three largest families, and

TABLE 4.-Families represented by more than $1 \%$ of the total number of taxa in any one of the biomes. Sv, Savanna; G, Grassland; D, Desert; N-K, Nama-Karoo; SK, Succulent Karoo; F, Fynbos. The number in the matrix is the rank according to number of taxa in the family in a given biome, with ' 1 ' signifying the largest family in the biome

\begin{tabular}{lrrrrrr}
\hline & Sv & G & D & N-K & SK & F \\
& & & & & \\
4a. Families comprising more than & $1 \%$ & of the total number of \\
taxa in all biomes & & & & & & \\
Asteraceae & 3 & 1 & 2 & 1 & 1 \\
Poaceae & 1 & 2 & 1 & 2 & 4 & \\
Fabaceae & 2 & 3 & 3 & 3 & 3 & \\
Liliaceae & 5 & 4 & 10 & 4 & 5 & \\
Scrophulariaceae & 10 & 6 & 7 & 5 & 6 & 1 \\
Cyperaceae & 6 & 5 & 12 & 13 & 20 & \\
Euphorbiaceae & 8 & 12 & 11 & 9 & 19 & 2
\end{tabular}

4b. Families that distinguish Fynbos

\section{Presence of: \\ Ericaceae \\ Restionaceae \\ Rutaceae \\ Polygalaceae \\ Thymelaeaceae \\ Rhamnaceae \\ Rosaceae \\ Lobeliaceae \\ High rank of: \\ Proteaceae}

Absence or low rank of:

$\begin{array}{lrrrrr}\text { Asclepiadaceae } & 9 & 7 & 13 & 10 & 15 \\ \text { Scrophulariaceae } & 10 & 6 & 7 & 5 & 6\end{array}$

4c. Families that distinguish Savanna

Presence of:

Verbenaceae

High rank of:

Rubiaceae

Absence of:

Mesembry an themaceae

21

$4 \quad 11$

$\begin{array}{lllll}13 & 8 & 8 & 7 & 13\end{array}$

4d. Families that distinguish Grassland

High rank of:

Orchidaceae

Lamiaceae

Absence of:

Sterculiaceae

Aizoaceae

$\begin{array}{rrrrrr}14 & 8 & & & & 11 \\ 11 & 9 & & 20 & & \\ & & & & & \\ 16 & & 14 & 11 & 14 & 27 \\ 15 & & 4 & 7 & 8 & 23\end{array}$

4e. Families that distinguish Nama-Karoo

No families form more than $1 \%$ of flora only in Nama-Karoo. No families have high rank only in Nama-Karoo.

No families are absent only from Nama-Karoo.

4f. Families that distinguish Succulent Karoo

High rank of:

Iridaceae

Crassulaceae

Geraniaceae
17
14

$\begin{array}{rrrrr}14 & & 14 & 2 & 4 \\ & & 12 & 9 & 19 \\ & 23 & 16 & 10 & 16\end{array}$

4g. Families that distinguish Desert

Presence of:

Burseraceae

17

High rank of:

$\begin{array}{llll}\text { Chenopodiaceae } & 5 & 15 & 18 \\ \text { Capparaceae } & 9 & 24 & \end{array}$

Capparaceae

Absence of:

$\begin{array}{llllll}\text { Iridaceae } & 17 & 10 & 14 & 2 & 4\end{array}$

4h. Families that link summer rainfall biomes

$\begin{array}{lrrrr}\text { Presence of: } & 7 & 19 & 6 & 6 \\ \text { Acanthaceae } & 12 & 17 & 21 & 19 \\ \text { Malvaceae } & 11 & 9 & & 20 \\ \text { Lamiaceae } & 19 & & 22 & 22 \\ \text { Cucurbitaceae } & 18 & & 16 & \\ \text { Amaranthaceae } & 4 & 11 & & \\ \text { Rubiaceae } & 13 & 15 & & \\ \text { Convolvulaceae } & 20 & 20 & & \\ \text { Anacardiaceae } & & 22 & 19 & 21 \\ \text { Solanaceae } & & & 9 & 24 \\ \text { Capparaceae } & & & 18 & 23 \\ \text { Boraginaceae } & & & & \end{array}$

4i. Families that link winter rainfall biomes

Presence of:

$\begin{array}{lll}\text { Proteaceae } & 17 \quad 6\end{array}$

Oxalidaceae $\quad 11 \quad 21$

$\begin{array}{lll}\text { Campanulaceae } & 21 & 18\end{array}$

Low rank of:

$\begin{array}{lllllll}\text { Poaceae } & 1 & 2 & 1 & 2 & 4 & 5\end{array}$

$\begin{array}{lllllll}\text { Euphorbiaceae } & 8 & 12 & 11 & 9 & 19 & 24\end{array}$

4j. Families that link arid biomes

Presence of:

$\begin{array}{rrrr}\text { Chenopodiaceae } & 5 & 15 & 18\end{array}$

$\begin{array}{lrrr}\text { Zygophyllaceae } & 15 & 17 & 22\end{array}$

High rank of:

Aizoaceae

Mesembry an themaceae

15

$\begin{array}{lllll} & 4 & 7 & 8 & 23 \\ 13 & 8 & 8 & 7 & 13\end{array}$

4k. Families that link Grassland and/or Nama-Karoo to Succulent Karoo and/or Fynbos

Presence of:

Crassulaceae

Brassicaceae

Selaginaceae

Geraniaceae

Amaryllidaceae

Apiaceae

High rank of:

Iridaceae

Orchidaceae

14

23

21

16

18

$\begin{array}{lll}185 & 13 & 25\end{array}$

$\begin{array}{llll}23 & 16 & 10 & 16\end{array}$

$\begin{array}{rrrllr}17 & 10 & 14 & 2 & 4 \\ 14 & 8 & & & & 11\end{array}$


Restionaceae, Rutaceae and Proteaceae among the ten largest families in Fynbos only. In contrast, Asclepiadaceae is not important, and only in Fynbos is Scrophulariaceae not one of the ten largest families. Savanna (Table 4c) is distinguished by one important family, Verbenaceae, one family, Rubiaceae, that ranks among the ten largest in no other biome, and one family, Mesembryanthemaceae, that does not occur among the important families. Grassland (Table 4d) is distinguished by the high rank of Orchidaceae and Lamiaceae, which are among the ten largest families only in this biome, and only here are Sterculiaceae and Aizoaceae absent from the important families. Nama-Karoo (Table 4e) is the only biome which is not distinguished from the others by differential occurrence of families. Succulent Karoo (Table $4 \mathrm{f}$ ) is distinguished by the high rank of Iridaceae, which is one of the three largest families, and Crassulaceae and Geraniaceae, which are among the ten largest families only in this biome. Desert (Table $4 \mathrm{~g}$ ) is distinguished by the occurrence of Pedaliaceae and Burseraceae as important families, by the occurrence of Chenopodiaceae and Capparaceae among the ten largest families, and by the absence of Iridaceae as an important family.

A number of families indicate floristic relationships between biomes with different rainfall seasonality and amount. The four summer rainfall biomes (Table $4 \mathrm{~h}$ ) are variously linked by 11 families that do not occur as an important component of the winter rainfall biomes. Winter rainfall biomes (Table $4 \mathrm{i}$ ) are linked by the occurrence of three families, Proteaceae, Oxalidaceae and Campanulaceae, that are not important in summer rainfall areas, and one family, Poaceae, that ranks first or second in summer rainfall biomes, but has a lower rank in the winter rainfall areas.

In contrast to the above groupings based on rainfall seasonality, other families link biomes with similar amounts of rainfall. The arid biomes are linked by four families (Table 4j). Chenopodiaceae and $\mathrm{Zy}$ gophyllaceae are important, and Aizoaceae and Mesembryanthemaceae are among the ten largest families only in the arid biomes. Finally, a group of six families, all with low ranking, weakly links the summer rainfall biomes Grassland and Nama-Karoo to the winter rainfall biomes (Table $4 \mathrm{k}$ ). Savanna is not linked to the winter rainfall biomes at family level.

\section{Centres of diversity of large genera}

The large genera (with 10 or more taxa) with centres of diversity in one, two or three biomes are listed in Appendices 1-3. The large genera with no apparent centre of diversity are listed in Appendix 4. Figure 5 summarizes this information by showing the numbers and percentages of large genera with centres of diversity within and shared between the biomes.

Only in the case of Fynbos and Savanna are more than half the large genera centred in a single biome, whereas each of the other four biomes shares more than half its large genera with another biome. The highest number of large genera have their centre of

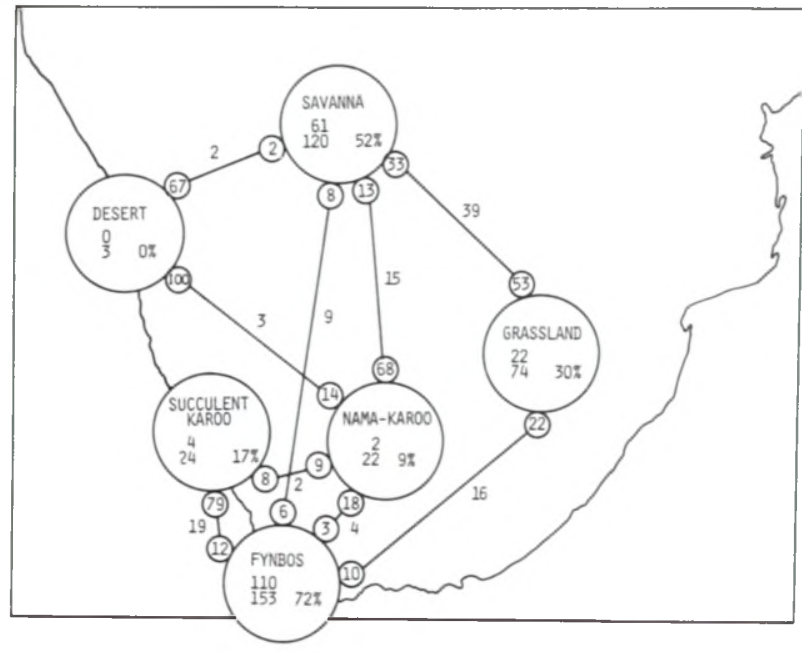

FIGURE 5. - Number and percentage of large genera (10 or more taxa) with centres of diversity in each biome and shared between biomes. In each large circle, the upper number is the number of large genera with a centre of diversity only in that biome, the lower number is the total number of large genera with a centre of diversity in that biome, and the percentage is the percentage of large genera with a centre of diversity only in that biome. The number in each small circle is the percentage of genera shared between pairs of biomes, and the number on the line between a pair is the number of genera with shared centres of diversity. Absence of linkage lines indicates no large genera in common.

diversity in Fynbos, and $72 \%$ of these genera are centred only in Fynbos. Fynbos is a shared centre of diversity for similar numbers of genera with Succulent Karoo and with Grassland, and for low numbers with Savanna and with Nama-Karoo. No genera have centres of diversity in both Fynbos and Desert. In Savanna, as in Fynbos, over half the large genera have centres of diversity in no other biome, and Savanna also shares genera with centres of diversity in four other biomes. No genera have centres of diversity in both Savanna and Succulent Karoo. For Grassland, over half the large genera share their centres of diversity with Savanna, and nearly a quarter share their centres of diversity with Fynbos. Grassland shares large genera only with Savanna and Fynbos, and no genera have centres of diversity in both Grassland and Nama-Karoo, Grassland and Succulent Karoo or Grassland and Desert. A very low percentage of large genera have their centre of diversity in Nama-Karoo alone. Over two-thirds of large genera in Nama-Karoo share their centre of diversity with Savanna, and Nama-Karoo shares genera with centres of diversity in all biomes except Grassland. In Succulent Karoo, a very high percentage of large genera shares a centre of diversity with Fynbos, and a low percentage shares a centre of diversity with Nama-Karoo. Succulent Karoo shares large genera only with Fynbos and Nama-Karoo, and no genera have centres of diversity in both Succulent Karoo and Savanna, Succulent Karoo and Grassland or Succulent Karoo and Desert. Only two genera have their diversity centred in both of the 'karroid' biomes, and this is the lowest percentage of shared large genera for either Nama-Karoo or Succulent Karoo. Only three large genera have a centre of diversity in Desert, and all three are shared with 
50

25

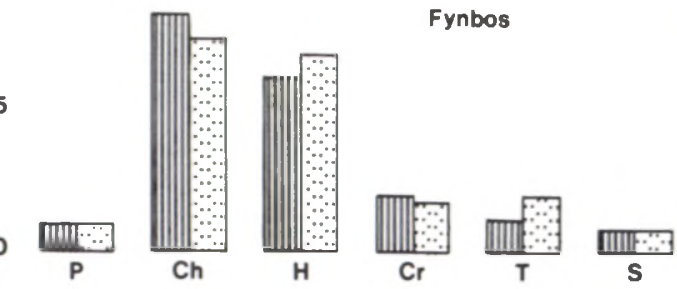

50

25

0

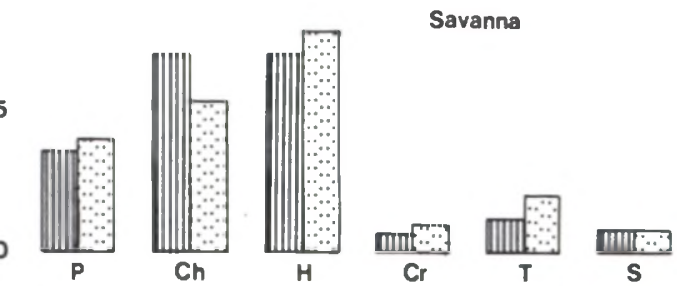

50

25

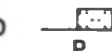

Ch
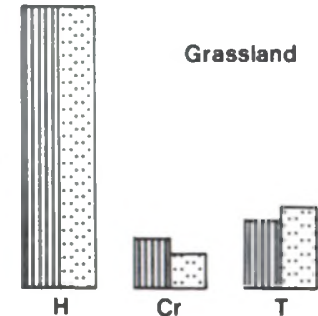

Nama-Karoo

25

0
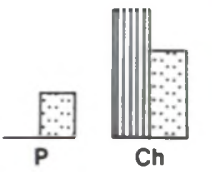

50

25
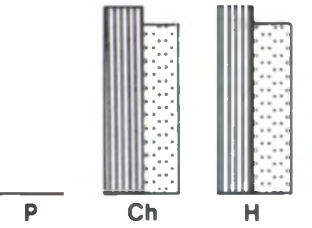

Succulent Karoo

50

25

0
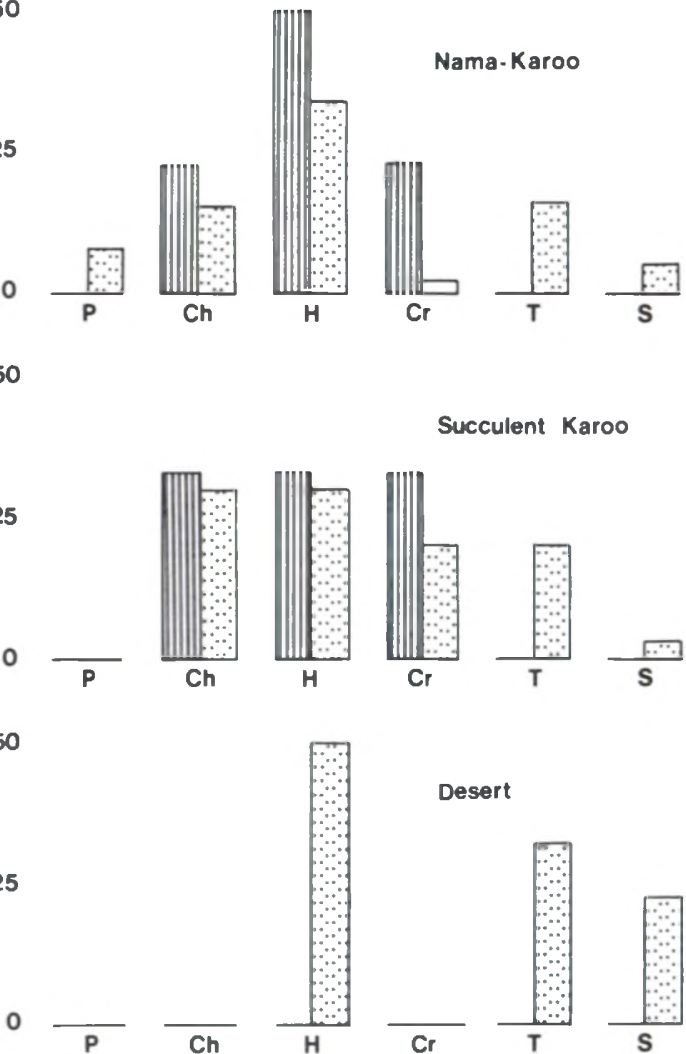

FIGURE 6. - Life form spectra of large genera (10 or more taxa) for each biome. Life forms of genera with centres of diversity only in a particular biome are shown by stripes, and life forms in all genera with centres of diversity in a particular as well as in other biomes are shown by stippling. Life forms are indicated by the following symbols: $\mathrm{P}=$ phanerophytes; $\mathrm{Ch}=$ chamaephytes; $\mathrm{H}=$ hemicryptophytes; $\mathrm{Cr}=$ cryptophytes; $\mathrm{T}=$ therophytes; $\mathrm{S}=$ succulents.
Savanna or with Nama-Karoo. No genera have centres of diversity in both Desert and Grassland, Desert and Succulent Karoo, or Desert and Fynbos.

\section{Life forms and centres of diversity of large genera}

Figure 6 shows life form spectra for large genera with centres of diversity either only in one or in more than one biome. The basis for plant classification is that floral characters are conservative at family and genus level, whereas vegetative characters can be variable between members of a higher category. Raunkiaer's life forms indicate broad basic differences in vegetative states, depending on the position of the perennating bud, and indicate differences in utilization of resources. The fact that a genus has many species and infraspecific taxa in a certain biome suggests that the adaptations displayed by the taxa are compatible with the environment of that biome. Thus the differences in characteristics of the genera, as illustrated by life forms, can show convergent adaptations in a number of separate evolutionary lines to the conditions in the biome. However, a centre of diversity for a genus in a particular biome does not imply that speciation occurred either in that biome, or under current environmental conditions.

The biomes are characterized by differences in the life forms reported in the large genera. In Fynbos, chamaephytes are the most commonly reported life form in the large genera. In Savanna, phanerophytes are reported more frequently than in any other biome. For Grassland, nearly half the life forms reported are hemicryptophytes. Grassland differs from Savanna by having fewer phanerophytes and chamaephytes (the woody component), and from NamaKaroo by having fewer cryptophytes. Nama-Karoo is similar to Grassland, but with more cryptophytes reported among the few genera with their centre of diversity in Nama-Karoo only. Succulent Karoo is remarkable because it has similar values for chamaephytes, hemicryptophytes and cryptophytes. The comparative value for cryptophytes is far higher than for any other biome, and phanerophytes are not reported at all. The life form spectrum for Desert may be misleading because it is based on three genera only, and therefore it is not considered further.

The differences in occurrence of each of the life forms in the biomes can also be examined. Phanerophytes appear only in genera with a centre of diversity in Fynbos or Savanna. Chamaephytes and hemicryptophytes show a basic difference between the summer and the winter rainfall biomes. Chamaephytes are reported most often in winter rainfall Fynbos and Succulent Karoo. Hemicryptophytes are the most abundant life form in the summer rainfall Savanna, Grassland, Nama-Karoo and Desert. Cryptophytes occur in low numbers in all the biomes, but are reported often only in genera with their centre of diversity in Succulent Karoo, and to a lesser extent, Nama-Karoo. Therophytes are reported in all biomes, but are less frequently reported in genera of which the centre of diversity is confined to a single biome, and are more frequently reported in genera with centres in more than one 
biome. Succulents are reported in all biomes, but the mesic biomes Fynbos, Savanna and Grassland, have succulents reported in genera with centres in each one, while the more arid Succulent Karoo and Nama-Karoo have succulents reported only in genera with centres of diversity in more than one biome.

\section{Floristic characteristics and relationships of the biomes}

\section{Fynbos}

Fynbos has the largest number of taxa, the highest percent of unique taxa, the largest number of important families that do not occur in any other biome, and the greatest number of centres of diversity for large genera. At species level, the Sorenson's coefficient of similarity and the percentage of shared taxa show that Fynbos is most closely related to Succulent Karoo, the other winter rainfall biome. At the generic level, Fynbos shares more centres of diversity for large genera with Succulent Karoo than with any other biome. At the family level, Fynbos is linked only to Succulent Karoo by four important families. The less-marked relationship between Fynbos and Grassland will be discussed under Grassland below.

\section{Savanna}

Savanna is second to Fynbos in number of taxa, percentage of unique taxa, and in number of centres of diversity for large genera. However, Savanna is distinguished at family level by only three families, while it is linked to the other summer rainfall biomes by eight families. The closest relationship of Savanna is to Grassland, as shown by the very high Sorenson's coefficient of similarity and the percentage of shared taxa, the number of large genera with centres of diversity in both Savanna and Grassland, and the six families that link them, three of which are important only in Savanna and Grassland. A weaker relationship between Savanna and NamaKaroo is shown by a high Sorenson's coefficient and the percentage of shared taxa, a considerable number of large genera with centres of diversity in both Savanna and Nama-Karoo, and by four families that link them.

\section{Grassland}

A moderately large number of taxa is reported for Grassland, which is distinguished by four families. Its relationship with Savanna is the closest demonstrated in this study, as discussed above. Grassland shows similar moderate Sorenson's coefficients with both Nama-Karoo and Fynbos, but other comparisons show that Grassland is in fact more closely related to Fynbos than to Nama-Karoo. The percentage of Grassland taxa shared with Fynbos is far higher than the percentage shared with Nama-Karoo, and a number of large genera, nearly all hemicryptophytes, have centres of diversity in both Grassland and Fynbos, while no large genera have centres of diversity in both Grassland and Nama-Ka- roo. At family level, Grassland is linked to NamaKaroo only by families that also link it to Savanna (Table $4 \mathrm{~h}$ ) or to Fynbos (Table $4 \mathrm{k}$ ), while it is linked independently to Fynbos by two families (Table 4k).

\section{Nama-Karoo}

Nama-Karoo is not well defined floristically in this study. At species level, its number of taxa is low, particularly with respect to its large area, and the percentage of unique taxa is very low, hardly higher than that of Desert. Nama-Karoo is the only biome for which all Sorenson's coefficients except one (to Fynbos) are greater than 20. Over half of Nama-Karoo taxa are shared with Savanna, about a third are shared with Grassland and another third with Fynbos. At generic level, few large genera have a centre of diversity in Nama-Karoo, and of these, more have a shared centre of diversity with Savanna, with Fynbos or with Desert than are centred in Nama-Karoo alone. At family level, Nama-Karoo is the only biome that cannot be defined by differential occurrence of important families. It is linked to all the other summer rainfall biomes, and also to the winter rainfall Succulent Karoo through the arid biomes.

\section{Succulent Karoo}

The number of taxa reported for Succulent Karoo is similar to that of Nama-Karoo, but the area covered is about a quarter as large, and Succulent Karoo has more unique taxa. It is distinguished from other biomes by three important families. Succulent Karoo is shown by Sorenson's coefficients, by percentage of shared taxa and by centres of diversity of large genera to be related floristically both to Fynbos and Nama-Karoo. The much higher values in every case show that the relationship is strongest to Fynbos (see Fynbos above). Over half the Succulent Karoo taxa and over three quarters of the large genera are shared with Fynbos. At family level, the strong links of Succulent Karoo to Fynbos are shown by four families that are important only in these two biomes, whereas at family level Succulent Karoo is linked to Nama-Karoo only through the group of families that links the three arid biomes.

\section{Desert}

A very small number of taxa are reported for Desert, and the percentage of unique taxa is lower than for any other biome. There are no large genera with a centre of diversity in Desert alone. However, Desert is distinguished by four important families. Relationships of the Desert flora are shown by Sorenson's coefficients and by the percentage of shared taxa, to be highest with Savanna and with Nama-Karoo, and it is only with these two biomes that Desert shares centres of diversity for large genera. In addition, Desert is linked to Nama-Karoo by ten families, two of which are important only in Desert and Nama-Karoo, and it is linked to Savanna by four families, one of which is important only in Desert and Savanna. Desert is also linked to the arid but winter rainfall Succulent Karoo by four families. 


\section{Relationships}

The distribution of species, genera and families and the life form spectra shows that the biomes fall floristically into two groups, which correspond to the summer rainfall region (Savanna, Grassland, NamaKaroo, Desert) and the winter rainfall region (Fynbos, Succulent Karoo). The present analysis of 14000 taxa therefore supports and extends the 'winter rainfall biome' concept first put forward on the basis of a few genera by Bayer (1984). A detailed study of grass subfamily distributions also shows a similar basic division, with Chloridoideae and Panicoideae most abundant in summer rainfall areas and Arundinoideae most abundant in winter rainfall areas (Gibbs Russell 1986).

Nama-Karoo and Succulent Karoo, which have previously been placed together at highest level in all vegetation studies except that of Rutherford \& Westfall (1986), are not closely related floristically. Nama-Karoo is more closely related to Savanna than to Succulent Karoo, and Succulent Karoo is more closely related to Fynbos than to Nama-Karoo.

Within the summer rainfall group, at species level, the strongest relationship is between Savanna and Grassland, with a weaker relationship between Savanna and Nama-Karoo. The same relationships are shown at generic level, and the distinctness of NamaKaroo from Grassland and of Desert from Succulent Karoo is emphasized. At family level, particular families link and demarcate the summer rainfall biomes and the winter rainfall biomes, but another group of families complicates this simple difference by linking the arid biomes of both summer and winter rainfall regimes.

Secondary links connect the two major groups through Nama-Karoo, which lies between the other biomes geographically. Nama-Karoo is ill-defined as an entity, and is strongly linked at species, genus and family level to Savanna and Desert; it is more weakly linked at species and family level to Succulent Karoo and at genus level to Fynbos. Grassland, which is very strongly allied to Savanna, shows a secondary link to Fynbos, independent of Nama-Karoo, at species, genus and family level.

\section{CONCLUSIONS}

At the highest level of floristic comparison the winter rainfall biomes and the summer rainfall biomes form two separate groups. Within these groups, each biome is floristically distinct at the level of species and infraspecific taxa, whether measured by Sorenson's coefficient of similarity or by percentage of shared taxa, and each biome (except Desert) is rich in taxa. Each is a centre of diversity for certain large genera, and the life form spectrum for these genera is different for each biome. Each (except Nama-Karoo) is distinguished by differences in the occurrence of important plant families.

The floristic distinctness of the biomes, coupled with high taxon numbers, implies that each should be studied and managed as a separate entity. Because of the high numbers of species and infraspecific taxa, it is unlikely that conservation of limited areas in nature reserves will protect a large proportion of the taxa in any one biome.

This study is hampered by the dearth of specimen records from arid areas, and for this reason it may be criticized for being too preliminary. However, the trends indicated should serve as stimulus to more precise analyses. Unfortunately precision can only be achieved when primary data are available to compile more complete and accurate checklists. This should be done through bringing together records from many herbaria and from literature, and most important, through rationally planned specimen collecting designed to cover all biomes adequately.

The conclusions are based on plant distributions as they are now known, that result from interactions over a long geological, climatological and evolutionary history. It is not apparent to what extent these distributions have been influenced by present or past environments. However, listing and comparing the taxa in each biome is the first step in unravelling the events that have led to the formation of its characteristic flora. PRECIS has given us a preliminary look that will allow the generation of hypotheses for more rigorous testing using stronger data sets and more refined techniques.

\section{ACKNOWLEDGEMENTS}

The existence of PRECIS is due to the foresightedness and tenacity of Dr B. de Winter, who stood by the system from its beginning. J. C. Mogford searched PRECIS for the basic species lists, and B. C. de Wet wrote computer programs to generate subsidiary lists. R. H. Westfall, C. Hilton-Taylor, E. J. Moll and R. M. Cowling discussed particular points. W. Roux provided technical assistance and B. B. Gibbs assisted with mapping.

\section{REFERENCES}

ACOCKS, J. P. H. 1975. Veld types of South Africa, edn 2. Memoirs of the Botanical Survey of South Africa No. 40.

BAYER, M. B. The Cape Flora and the Karoo. Veld and Flora 70: $17-19$.

BOND, P. \& GOLDBLATT, P. 1984. Plants of the Cape Flora - a descriptive catalogue. Journal of South African Botany Supplement 13.

BRENAN, J. P. M. 1978. Some aspects of the phytogeography of tropical Africa. Annals of the Missouri Botanical Garden 65: $437-478$.

DYER, R. A. 1975. The genera of southern African flowering plants, Vol. 1. Dicotyledons. Department of Agricultural Technical Services, Pretoria.

DYER, R. A. 1976. The genera of southern African flowering plants, Vol. 2. Monocotyledons. Department of Agricultural Technical Services, Pretoria.

GIBBS RUSSELL, G. E. 1975. Comparison of the size of various African floras. Kirkia 10: 123-140.

GIBBS RUSSELL, G. E. 1985a. PRECIS, the National Herbarium's computerized information system. South African Journal of Science 81: 62-65.

GIBBS RUSSELL, G. E. 1985b. Analysis of the size and composition of the southern African flora. Bothalia 15: 613-630.

GIBBS RUSSELL, G. E. 1986. Significance of different centres of diversity in subfamilies of Poaceae in southern Africa. Palaeoecology of Africa 17: 183-192.

GIBBS RUSSELL, G. E. \& GONSALVES, P. 1984. PRECIS a curatorial and phytogeographic system. In R. Allkin \& F. A. Bisby, Databases in systematics, the Systematics Association Special Volume No. 26. Academic Press, London. 
GIBBS RUSSELL, G. E., RETIEF, E. \& SMOOK, L. 1984. Intensity of plant collecting in southern Africa. Bothalia 15: $131-138$.

GOLDBLATT, P. 1978. Analysis of the flora of southern Africa: its characteristics, relationships and origins. Annals of the Missouri Botanical Garden 65: 369-436.

HUNTLEY, B. J. 1984. Characteristics of southern African biomes. In P. de V. Booysen \& N. M. Tainton, Ecological effects of fire in South African ecosystems. Springer Verlag, Berlin.

RAUNKIAER, C. 1934. The life forms of plants and statistical plant geography. Oxford University Press, Oxford.

RUTHERFORD, M. C. \& WESTFALL, R. H. 1986. The biomes of southern Africa - an objective categorization. Memoirs of the Botanical Survey of South Africa No. 54.

SCHEEPERS, J. C. 1982. The status of conservation in South Africa. Journal of the South African Biological Society 23: 64-71.

SORENSON, T. 1948. A method for establishing groups of equal magnitude in plant sociology based on similarity of species content. Kongelige Dansk Videnskabernes Selskab 5: 1-34.

WERGER, M. J. A. 1978. Biogeographical division of southern Africa. In M. J. A. Werger, Biogeography and ecology of southern Africa. Junk, The Hague.

WHITE, F. 1983. Vegetation of Africa. UNESCO, Paris.

APPENDIX 1.- Large genera (10 taxa or more) with centre of diversity in one biome. * = genera reported only from a single biome. Life forms are abbreviated: P, phanerophyte; Ch, chamaephyte; $\mathrm{H}$, hemicryptophy te; $\mathrm{Cr}$, cryptophy te; $T$, therophyte; $S$, succulent

\begin{tabular}{c} 
a. Large genera with centre of diversity reported for Fynbos only \\
Family and genus \\
$\begin{array}{c}\text { Total no. \% of the } \\
\text { of taxa reported taxa Life form } \\
\text { reported in Fynbos }\end{array}$ \\
\hline
\end{tabular}

Pottiaceae

Tortula

Poaceae

Merxmuellera

Pentaschistis

Cyperaceae

Ficinia

Isolepis

Tetraria

Restionaceae

Restio

Chondropetalum*

Elegia*

Leptocarpus

Thamnochortus

Hypodiscus*

Juncaceae

Juncus

Liliaceae s.l.

Wurmbea

Trachy andra

Haworthia

Ornithogalum

Lachenalia

Hypoxidaceae

Spiloxene

Iridaceae

Romulea

Galaxia

Moraea

Homeria

Bobartia*

Aristea

Geissorhiza

Ixia

Tritonia

Gladiolus

Tritoniopsis*

Watsonia

\begin{tabular}{|c|c|}
\hline 12 & 83 \\
\hline 12 & 66 \\
\hline 47 & 82 \\
\hline 54 & 98 \\
\hline 19 & 78 \\
\hline 35 & 97 \\
\hline 09 & 94 \\
\hline 19 & 100 \\
\hline 36 & 100 \\
\hline 22 & 100 \\
\hline 29 & 100 \\
\hline 12 & 100 \\
\hline 19 & 89 \\
\hline 12 & 91 \\
\hline 44 & 54 \\
\hline 22 & 63 \\
\hline 44 & 59 \\
\hline 46 & 82 \\
\hline 15 & 86 \\
\hline 51 & 62 \\
\hline 11 & 81 \\
\hline 62 & 64 \\
\hline 22 & 63 \\
\hline 12 & 100 \\
\hline 29 & 82 \\
\hline 58 & 98 \\
\hline 41 & 97 \\
\hline 17 & 58 \\
\hline 03 & 72 \\
\hline 13 & 100 \\
\hline 16 & 81 \\
\hline
\end{tabular}

Orchidaceae

Holothrix

Satyrium

Disa

Monadenia

Corycium

Proteaceae

Paranomus

Serruria

Spatalla

Protea

Leucospermum

Leucadendron

Santalaceae

Thesium

Mesembryanthemaceae

Drosanthemum

Erepsia*

Lampranthus

Caryophyllaceae

Silene

Droseraceae

Drosera

Crassulaceae

Crassula

Adromischus

Bruniaceae

Raspalia

Berzelia

Rosaceae

Cliffortia

Fabaceae

Cyclopia*

Podalyria

Priestleya

Rafnia

Lebeckia

Aspalathus

Geraniaceae

Pelargonium

Oxalidaceae

Oxalis

Rutaceae

Agathosma

Adenandra*

Acmadenia*

Diosma

Euchaetis

Polygalaceae

Polygala

Muraltia

Euphorbiaceae

Clutia

Rhamnaceae

Phylica

Malvaceae

Anisodontea

Sterculiaceae

Hermannia

Thymelaeaceae

Gnidia

Struthiola

Lachnaea

Passerina

Apiaceae

Centella

Peucedanum

Ericaceae

Erica

Blaeria*

Grisebachia

Simocheilus*

Syndesmanthus*

Schyphogyne*

Plumbaginaceae

Limonium

Gentianaceae

Chironia

Boraginaceae

Lobostemon
H

H

$\mathrm{Ch}, \mathrm{H}, \mathrm{S}$

$\mathrm{Ch}, \mathrm{S}$

$\mathrm{Ch}$

$100 \quad \mathrm{Ch}$

100

100

100

100

70

97

89

Ch

Ch

$\mathrm{Ch}, \mathrm{H}$

$\mathrm{Ch}, \mathrm{H}$

$\mathrm{P}, \mathrm{Ch}$

$\mathrm{Ch}, \mathrm{H}, \mathrm{C}_{\mathrm{I}}, \mathrm{T}$

$\mathrm{Ch}, \mathrm{H}, \mathrm{Cr}, \mathrm{T}$

100

100

100

100

100

Ch
Ch
Ch
Ch
Ch

$\mathrm{Ch}, \mathrm{H}$

$\mathrm{Ch}$

$\mathrm{Ch}$

$\mathrm{P}, \mathrm{Ch}$

$\mathrm{Ch}, \mathrm{H}$

Ch

$\mathrm{Ch}$

$\mathrm{Ch}$

$\mathrm{Ch}$

$\mathrm{H}$

Ch, H

Ch

$\mathrm{Ch}$

$\mathrm{Ch}$

$\mathrm{Ch}$ 


\begin{tabular}{|c|c|c|c|}
\hline \multicolumn{4}{|l|}{ Scrophulariaceae } \\
\hline Polycarena & 23 & 60 & $\mathrm{H}, \mathrm{T}$ \\
\hline Harveya & 15 & 73 & $\mathrm{H}$ \\
\hline \multicolumn{4}{|l|}{ Selaginaceae } \\
\hline Selago & 61 & 63 & $\mathrm{Ch}$ \\
\hline \multicolumn{4}{|l|}{ Rubiaceae } \\
\hline Anthospermum & 17 & 70 & $\mathrm{Ch}$ \\
\hline \multicolumn{4}{|l|}{ Campanulaceae } \\
\hline Roella* & 23 & 100 & $\mathrm{Ch}, \mathrm{H}$ \\
\hline Prismatocarpus & 21 & 90 & $\mathrm{Ch}, \mathrm{H}$ \\
\hline Lightfootia & 35 & 77 & $\mathrm{Ch}, \mathrm{H}$ \\
\hline \multicolumn{4}{|l|}{ Lobeliaceae } \\
\hline Cyphia & 27 & 55 & $\mathrm{H}, \mathrm{Cr}$ \\
\hline Lobelia & 51 & 70 & $\mathrm{Ch}, \mathrm{H}, \mathrm{T}$ \\
\hline Monopsis & 13 & 92 & $\mathrm{H}, \mathrm{T}$ \\
\hline \multicolumn{4}{|l|}{ Asteraceae } \\
\hline Mairea & 12 & 100 & $\mathrm{Ch}, \mathrm{H}$ \\
\hline Felicia & 62 & 66 & $\mathrm{Ch}, \mathrm{H}$ \\
\hline Helipterum & 11 & 100 & $\mathrm{H}, \mathrm{T}$ \\
\hline Stoebe & 21 & 100 & $\mathrm{Ch}$ \\
\hline Metalasia & 23 & 91 & $\mathrm{Ch}$ \\
\hline Relhania & 18 & 77 & $\mathrm{Ch}, \mathrm{T}$ \\
\hline Athanasia & 25 & 88 & $\mathrm{Ch}$ \\
\hline Cotula & 22 & 59 & $\mathrm{H}, \mathrm{T}$ \\
\hline Senecio & 182 & 48 & $\mathrm{Ch}, \mathrm{H}, \mathrm{S}$ \\
\hline Euryops & 46 & 54 & $\mathrm{Ch}, \mathrm{H}, \mathrm{T}$ \\
\hline Osteospermum & 56 & 66 & $\mathrm{Ch}, \mathrm{H}$ \\
\hline Ursinia & 37 & 78 & $\mathrm{Ch}, \mathrm{H}, \mathrm{T}$ \\
\hline Cullumia & 13 & 92 & $\mathrm{Ch}$ \\
\hline
\end{tabular}

\begin{tabular}{|c|c|c|c|}
\hline Aeschynomene & 10 & 80 & $\mathrm{Ch}, \mathrm{H}, \mathrm{T}$ \\
\hline Rhynchosia & 44 & 73 & $\mathrm{Ch}, \mathrm{H}$ \\
\hline Vigna & 14 & 100 & H \\
\hline \multicolumn{4}{|l|}{ Euphorbiaceae } \\
\hline Phyllanthus & 14 & 78 & $\mathrm{P}, \mathrm{Ch}, \mathrm{H}$ \\
\hline Croton & 10 & 100 & $\mathrm{P}, \mathrm{Ch}, \mathrm{H}$ \\
\hline Jatropha & 15 & 86 & $\mathrm{Ch}, \mathrm{H}$ \\
\hline Euphorbia & 123 & 46 & $\mathrm{P}, \mathrm{Ch}, \mathrm{H}, \mathrm{S}$ \\
\hline \multicolumn{4}{|l|}{ Anacardiaceae } \\
\hline Ozoroa & 13 & 84 & $\mathrm{P}, \mathrm{Ch}$ \\
\hline \multicolumn{4}{|l|}{ Vitaceae } \\
\hline Cyphostemma & 23 & 78 & $\mathrm{Ch}, \mathrm{H}$ \\
\hline \multicolumn{4}{|l|}{ Tiliaceae } \\
\hline Corchorus & 12 & 100 & $\mathrm{Ch}, \mathrm{H}$ \\
\hline Grewia & 24 & 91 & $\mathrm{P}, \mathrm{Ch}$ \\
\hline Triumfetta & 11 & 91 & $\mathrm{Ch}, \mathrm{H}$ \\
\hline \multicolumn{4}{|l|}{ Malvaceae } \\
\hline Abutilon & 16 & 93 & $\mathrm{P}, \mathrm{Ch}, \mathrm{H}$ \\
\hline Pavonia & 11 & 72 & $\mathrm{Ch}, \mathrm{H}$ \\
\hline Hibiscus & 45 & 93 & $\mathrm{P}, \mathrm{Ch}, \mathrm{H}, \mathrm{I}$ \\
\hline \multicolumn{4}{|l|}{ Sterculiaceae } \\
\hline Melhania & 10 & 100 & $\mathrm{Ch}, \mathbf{H}$ \\
\hline \multicolumn{4}{|l|}{ Ochnaceae } \\
\hline \multicolumn{4}{|l|}{ Elatinaceae } \\
\hline Bergia & 10 & 90 & $\mathrm{Ch}, \mathrm{H}$ \\
\hline \multicolumn{4}{|l|}{ Lythraceae } \\
\hline Nesaea & 16 & 87 & $\mathrm{Ch}, \mathrm{H}, \mathrm{T}$ \\
\hline \multicolumn{4}{|l|}{ Combretaceae } \\
\hline Combretum & 32 & 96 & $\mathrm{P}, \mathrm{Ch}$ \\
\hline \multicolumn{4}{|l|}{ Ebenaceae } \\
\hline Diospyros & 19 & 73 & $\mathrm{P}, \mathrm{Ch}$ \\
\hline \multicolumn{4}{|l|}{ Asclepiadaceae } \\
\hline Ceropegia & 21 & 95 & $\mathrm{H}, \mathrm{S}$ \\
\hline Huemia & 17 & 82 & $\mathrm{H}, \mathrm{S}$ \\
\hline \multicolumn{4}{|l|}{ Convolvulaceae } \\
\hline \multicolumn{4}{|l|}{ Verbenaceae } \\
\hline Clerodendrum & 10 & 100 & $\mathrm{P}, \mathrm{Ch}, \mathrm{H}$ \\
\hline \multicolumn{4}{|l|}{ Lamiaceae } \\
\hline Leonotis & 11 & 91 & $\mathrm{Ch}, \mathrm{H}$ \\
\hline \multicolumn{4}{|l|}{ Lentibulariaceae } \\
\hline Utricularia & 14 & 92 & $\mathbf{H}$ \\
\hline \multicolumn{4}{|l|}{ Acanthaceae } \\
\hline Barleria & 47 & 85 & $\mathrm{Ch}$ \\
\hline Blepharis & 35 & 65 & $\mathrm{Ch}, \mathrm{H}, \mathrm{T}$ \\
\hline Justicia & 24 & 87 & $\mathrm{Ch}, \mathrm{H}$ \\
\hline \multicolumn{4}{|l|}{ Rubiaceae } \\
\hline Kohautia & 14 & 85 & $\mathrm{Ch}, \mathrm{H}, \mathrm{T}$ \\
\hline Oldenlandia & 13 & 100 & $\mathrm{Ch}, \mathrm{H}$ \\
\hline Canthium & 14 & 92 & $\mathrm{P}, \mathrm{Ch}$ \\
\hline \multicolumn{4}{|l|}{ Asteraceae } \\
\hline Geigeria & 14 & 92 & $\mathrm{Ch}, \mathrm{H}$ \\
\hline Dicoma & 14 & 78 & $\mathrm{Ch}, \mathrm{H}$ \\
\hline
\end{tabular}

b. Large genera with centre of diversity reported for Savanna only
Family and genus $\begin{gathered}\text { Total no. \% of the } \\ \text { of taxa reported taxa Life form } \\ \text { reported in Savanna }\end{gathered}$

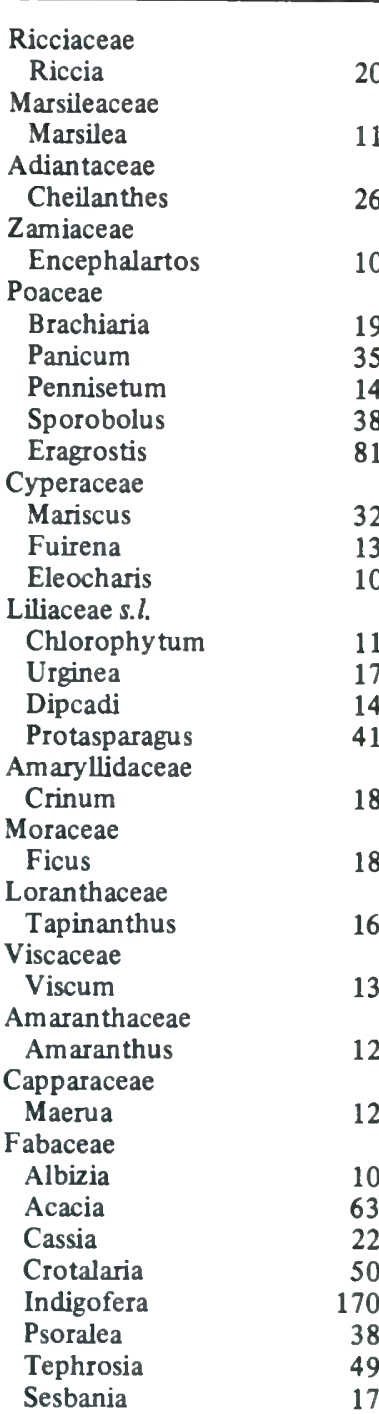

$\begin{array}{rrl}20 & 55 & \mathrm{H} \\ 11 & 90 & \mathrm{H} \\ 26 & 57 & \mathrm{H} \\ 10 & 70 & \mathrm{P}, \mathrm{Ch} \\ 19 & 100 & \mathrm{H} \\ 35 & 97 & \mathrm{H} \\ 14 & 64 & \mathrm{H} \\ 38 & 89 & \mathrm{H} \\ 81 & 88 & \mathrm{H} \\ 32 & 90 & \mathrm{H} \\ 13 & 76 & \mathrm{H} \\ 10 & 90 & \mathrm{H} \\ 11 & 54 & \mathrm{Cr} \\ 17 & 47 & \mathrm{Cr} \\ 14 & 92 & \mathrm{Cr} \\ 41 & 63 & \mathrm{Ch} \\ 18 & 94 & \mathrm{Cr} \\ 18 & 100 & \mathrm{P} \\ 16 & 100 & \mathrm{Ch}\end{array}$

$13 \quad 61$

$12 \quad 83$

$61 \quad \mathrm{Ch}$

$\mathrm{Ch}$

$\mathrm{T}$

P, Ch

P, Ch

$\mathrm{P}, \mathrm{Ch}$

$\mathrm{P}, \mathrm{Ch}, \mathrm{H}$

$\mathrm{Ch}, \mathrm{H}$

$\mathrm{Ch}, \mathrm{H}$

$\mathrm{Ch}, \mathrm{H}$

$\mathrm{Ch}, \mathrm{H}$

$\mathrm{P}, \mathrm{Ch}, \mathrm{H}$

$83 T$

$\mathrm{Ch}, \mathrm{H}$

c. Large genera with centre of diversity reported for Grassland only

Total no. \% of the

Family and genus of taxa reported taxa Life form reported in Grassland

\begin{tabular}{|c|c|c|c|}
\hline \multicolumn{4}{|l|}{ Cyperaceae } \\
\hline Carex & 13 & 69 & $\mathrm{H}$ \\
\hline \multicolumn{4}{|l|}{ Liliace ae $s . l$. } \\
\hline Kniphofia & 23 & 73 & $\mathbf{H}$ \\
\hline Agapanthus & 11 & 63 & $\mathbf{H}$ \\
\hline Tulbaghia & 12 & 75 & $\mathbf{H}$ \\
\hline \multicolumn{4}{|l|}{ Amaryllidaceae } \\
\hline Nerine & 14 & 57 & $\mathrm{Cr}_{\mathrm{r}}$ \\
\hline Cyrtanthus & 20 & 55 & $\mathrm{Cr}$ \\
\hline \multicolumn{4}{|l|}{ Iridaceae } \\
\hline Dierama & 10 & 100 & $\mathrm{Cr}_{\mathbf{r}}$ \\
\hline \multicolumn{4}{|c|}{ Mesembry an themaceae } \\
\hline Delosperma & 24 & 79 & Ch, H, S \\
\hline \multicolumn{4}{|l|}{ Portulacaceae } \\
\hline Anacampseros & 11 & 45 & Ch, H, S \\
\hline \multicolumn{4}{|l|}{ Brassicaceae } \\
\hline Lepidium & 13 & 53 & $\mathrm{Ch}, \mathrm{H}, \mathrm{T}$ \\
\hline
\end{tabular}




\begin{tabular}{|c|c|c|c|}
\hline \multicolumn{4}{|l|}{ Fabaceae } \\
\hline Lotononis & 33 & 45 & $\mathrm{Ch}, \mathrm{H}$ \\
\hline Pearsonia & 10 & 90 & $\mathrm{Ch}, \mathrm{H}$ \\
\hline \multicolumn{4}{|l|}{ Onagraceae } \\
\hline Oenothera & 12 & 91 & $\mathrm{Ch}, \mathrm{H}, \mathrm{T}$ \\
\hline \multicolumn{4}{|l|}{ Apiaceae } \\
\hline Alepidea & 13 & 92 & $\mathbf{H}$ \\
\hline \multicolumn{4}{|l|}{ Asclepiadaceae } \\
\hline Aspidoglossum & 12 & 83 & $\mathrm{H}$ \\
\hline Pachycarpus & 13 & 84 & $\mathrm{H}$ \\
\hline \multicolumn{4}{|l|}{ Lamiaceae } \\
\hline Stachys & 29 & 51 & $\mathrm{Ch}, \mathrm{H}, \mathrm{T}$ \\
\hline Salvia & 25 & 60 & $\mathrm{Ch}, \mathrm{H}$ \\
\hline \multicolumn{4}{|l|}{ Scrophulariaceae } \\
\hline \multirow{2}{*}{\multicolumn{4}{|c|}{ Gesneriaceae }} \\
\hline & & & \\
\hline \multicolumn{4}{|l|}{ Asteraceae } \\
\hline Helichrysum & 147 & 55 & $\mathrm{Ch}, \mathrm{H}$ \\
\hline Gerbera & 12 & 50 & \\
\hline \multicolumn{4}{|c|}{$\begin{array}{l}\text { d. Large genera with centre of diversity reported for Succulent } \\
\text { Karoo only }\end{array}$} \\
\hline Family and genus & $\begin{array}{l}\text { Total no. } \\
\text { of taxa } \\
\text { reported }\end{array}$ & $\begin{array}{l}\% \text { of the } \\
\text { reported taxa } \\
\text { in Succulent } \\
\text { Karoo }\end{array}$ & Life form \\
\hline \multicolumn{4}{|l|}{ Liliaceae s.l. } \\
\hline \multicolumn{4}{|l|}{$\begin{array}{l}\text { Androcymbium } \\
\text { Iridaceae }\end{array}$} \\
\hline Lapeirousia & 13 & 48 & $\mathrm{Cr}$ \\
\hline \multicolumn{4}{|l|}{ Aizoaceae } \\
\hline $\begin{array}{l}\text { Galenia } \\
\text { Crassulaceae }\end{array}$ & 26 & 61 & \\
\hline $\begin{array}{l}\text { Crassulaceae } \\
\text { Tylecodon }\end{array}$ & 13 & 76 & $\mathrm{Ch}, \mathrm{H}, \mathrm{S}$ \\
\hline \multicolumn{4}{|c|}{$\begin{array}{l}\text { e. Large genera with centre of diversity reported for Nama- } \\
\text { Karoo only }\end{array}$} \\
\hline Family and genus & $\begin{array}{l}\text { Total no. } \\
\text { of taxa } \\
\text { reported }\end{array}$ & $\begin{array}{l}\% \text { of the } \\
\text { reported taxa } \\
\text { in Nama- } \\
\text { Karoo }\end{array}$ & Life form \\
\hline \multicolumn{4}{|c|}{ Mesembry anthemaceae } \\
\hline Lithops & 12 & 83 & $\mathrm{H}, \mathrm{S}$ \\
\hline \multicolumn{4}{|l|}{ Asteraceae } \\
\hline Pentzia & 25 & 60 & $\mathrm{Ch}, \mathrm{H}$ \\
\hline
\end{tabular}

APPENDIX 2.-Large genera (10 taxa or more) with centres of diversity in two biomes. Life forms are abbreviated: $\mathrm{P}$, phanerophyte; $\mathrm{Ch}$, chamaephy te; $\mathrm{H}$, hemicryptophy te; $\mathrm{Cr}$, cryptophy te; T, therophyte; S, succulent

a. Large genera with centre of diversity reported for Savanna and Grassland

Total no. \% of reported

Family and genus of taxa taxa in: Life form reported Savanna Grassland

\begin{tabular}{lrrrl}
\hline $\begin{array}{l}\text { Aspleniaceae } \\
\text { Asplenium }\end{array}$ & 13 & 62 & 62 & $\mathrm{H}$ \\
$\begin{array}{l}\text { Poaceae } \\
\text { Andropogon }\end{array}$ & 12 & 67 & 83 & $\mathrm{H}$ \\
Hyparrhenia & 17 & 100 & 65 & $\mathrm{H}$ \\
Digitaria & 29 & 93 & 62 & $\mathrm{H}$ \\
Setaria & 17 & 88 & 59 & $\mathrm{H}$ \\
Aristida & 38 & 92 & 55 & $\mathrm{H}, \mathrm{T}$ \\
Cyperaceae & & & & \\
Cyperus & 63 & 84 & 54 & $\mathrm{H}, \mathrm{T}$ \\
Pycreus & 18 & 89 & 56 & $\mathrm{H}, \mathrm{T}$ \\
Kyllinga & 10 & 70 & 80 & $\mathrm{H}, \mathrm{T}$ \\
& & & &
\end{tabular}

Schoenoplectus

Bulbostylis

Scleria*

Commelinaceae

Commelina $\quad 19 \quad 95$

Liliaceae $s . l$.

Anthericum

Ledebouria

Hypoxidaceae

Hypoxis

Dioscoreaceae

Dioscorea

Orchidaceae

Habenaria

Eulophia

Polygonaceae

Polygonum

Chenopodiaceae

Chenopodium

Fabaceae

Eriosema

Euphorbiaceae

Acalypha

Chamaesyce

Anacardiaceae

Rhus

Malvaceae

Sida

Oleaceae

Jasminum

Asclepiadaceae

Asclepias

Brachystelma

Convolvulaceae

Convolvulus

Verbenaceae

Chascanum

Lamiaceae

Plectranthus

Hemizygia

Solanaceae

Solanum

Scrophulariaceae

Alectra

Rubiaceae

Pavetta

b. Large genera with centres of diversity reported for Savanna
and Nama-Karoo
$\begin{gathered}\text { Total no. } \% \text { of reported } \\ \text { of taxa } \\ \text { reported }\end{gathered}$ taxa in:
$\begin{gathered}\text { Favanna Nama- } \\ \text { Karoo }\end{gathered}$

Aizoaceae

Limeum

Capparaceae

Cleome

Boscia

Fabaceae

Melolobium

Burseraceae

Commiphora

Boraginaceae

Heliotropium

Solanaceae

Lycium

Scrophulariaceae

Aptosimum

Selaginaceae

Walafrida

Acanthaceae

Petalidium

Monechma

Cucurbitaceae

Cucumis 


\begin{tabular}{|c|c|c|c|c|}
\hline \multicolumn{5}{|c|}{$\begin{array}{l}\text { c. Large genera with centres of diversity reported for Savanna } \\
\text { and Fynbos }\end{array}$} \\
\hline Family and genus & $\begin{array}{c}\text { Total no. } \\
\text { of taxa } \\
\text { reported }\end{array}$ & \multicolumn{2}{|c|}{$\begin{array}{l}\% \text { of reported } \\
\text { taxa in: }\end{array}$} & Life form \\
\hline \multicolumn{5}{|l|}{ Dicranaceae } \\
\hline Campylopus & 13 & 62 & 77 & $\mathrm{H}$ \\
\hline \multicolumn{5}{|l|}{ Crassulaceae } \\
\hline Cotyledon & 11 & 45 & 55 & $\mathrm{Ch}, \mathrm{H}, \mathrm{S}$ \\
\hline \multicolumn{5}{|l|}{ Celastraceae } \\
\hline Cassine & 12 & 50 & 75 & P. Ch \\
\hline \multicolumn{5}{|l|}{ Ebenaceae } \\
\hline Euclea & 18 & 67 & 61 & $\mathrm{P}, \mathrm{Ch}$ \\
\hline \multicolumn{5}{|l|}{ Asclepiadaceae } \\
\hline Cynanchum & 10 & 50 & 50 & $\mathrm{Ch}, \mathrm{H}$ \\
\hline
\end{tabular}

d. Large genera with centres of diversity reported for Fynbos and Grassland

Family and genus $\begin{gathered}\text { Total no. } \\ \text { of taxa } \\ \text { reported }\end{gathered} \quad \begin{gathered}\% \text { of reported } \\ \text { taxa in: } \\ \text { Fynbos Grassland }\end{gathered}$ Life form

Bryaceae

Bryum

Poaceae

Agrostis

Orchidaceae

Disperis

Polygonaceae

Rumex

Chenopodiaceae

Atriplex

Caryophyllaceae

Dianthus

Fabaceae

Argyrolobium

Trifolium

Geraniaceae

Geranium

Gentianaceae

Sebaea

Asclepiadaceae

Schizoglossum

Rubiaceae

Galium

Asteraceae

Cineraria

(1)

17

5

$\begin{array}{lll}60 & 73 & \text { H } \\ 54 & 54 & \text { H } \\ 47 & 47 & \text { H }\end{array}$

13

77

77

$\mathrm{Ch}, \mathrm{H}$

$10 \quad 50 \quad 70 \quad \mathrm{Ch}, \mathrm{H}$

$\begin{array}{llll}18 & 44 & 50 & \mathrm{H}, \mathrm{T}\end{array}$

22

22
18

$\begin{array}{ll}50 & 59 \\ 61 & 55\end{array}$

Ch, $\mathrm{H}$

$\mathrm{H}$

12

$$
50
$$$$
50
$$

H, T

35

13

54

46

H, T

$\begin{array}{lll}46 & 62 & \mathrm{H}\end{array}$

13

77

54

$\mathrm{Ch}, \mathrm{H}$

20

50

60

$\mathrm{Ch}, \mathrm{H}$

e. Large genera with centres of diversity reported for Fynbos and Succulent Karoo

Total no. \% of reported

$\begin{array}{cc}\text { Family and genus } \begin{array}{c}\text { of taxa } \\ \text { reported }\end{array} & \begin{array}{c}\text { taxa in: } \\ \text { Fynbos Succulent }\end{array}\end{array}$ Karoo

\begin{tabular}{lllll}
\hline $\begin{array}{l}\text { Poaceae } \\
\text { Ehrharta }\end{array}$ & 29 & 90 & 45 & $\mathrm{H}$ \\
$\begin{array}{l}\text { Liliaceae } \\
\text { Bulbine }\end{array}$ & 23 & 65 & 48 & $\mathrm{Cr}$ \\
$\begin{array}{l}\text { Albuca } \\
\text { Amaryllidaceae }\end{array}$ & 22 & 55 & 55 & $\mathrm{Cr}$ \\
$\begin{array}{l}\text { Haemanthus } \\
\text { Gethyllis }\end{array}$ & 16 & 56 & 56 & $\mathrm{Cr}$ \\
$\begin{array}{l}\text { Iridaceae } \\
\quad \text { Hesperantha }\end{array}$ & 11 & 82 & 45 & $\mathrm{Cr}$ \\
$\begin{array}{c}\text { Babiana } \\
\text { Aizoaceae }\end{array}$ & 51 & 57 & 49 & $\mathrm{Cr}$ \\
$\begin{array}{l}\text { Pharnaceum } \\
\text { Tetragonia }\end{array}$ & 22 & 77 & 55 & $\mathrm{Ch}, \mathrm{H}, \mathrm{T}$ \\
$\begin{array}{c}\text { Brassicaceae } \\
\text { Heliophila }\end{array}$ & 27 & 56 & 67 & $\mathrm{Ch}, \mathrm{H}, \mathrm{T}$ \\
$\begin{array}{c}\text { Fabaceae } \\
\text { Wiborgia }\end{array}$ & 10 & 72 & 47 & $\mathrm{Ch}, \mathrm{H}, \mathrm{T}$ \\
\end{tabular}

Scrophulariaceae

$\begin{array}{lllll}\begin{array}{l}\text { Scrophulariaceae } \\ \text { Diascia }\end{array} & 11 & 45 & 50 & \text { H, T } \\ \begin{array}{c}\text { Nemesia } \\ \text { Manulea }\end{array} & 39 & 62 & 46 & \text { Ch, H, T } \\ \begin{array}{c}\text { Selaginaceae } \\ \text { Hebenstretia }\end{array} & 32 & 50 & 50 & \mathrm{Ch}, \mathrm{H}, \mathrm{T} \\ \begin{array}{c}\text { Asteraceae } \\ \text { Othonna }\end{array} & 23 & 57 & 48 & \mathrm{Ch}, \mathrm{H}, \mathrm{T} \\ \text { Arctotis } & 55 & 55 & 58 & \mathrm{Ch}, \mathrm{H}, \mathrm{S} \\ \text { Gazania } & 34 & 68 & 53 & \mathrm{H} \\ & 18 & 61 & 61 & \mathrm{H}, \mathrm{T}\end{array}$

$$
\begin{aligned}
& \text { f. Large genera with centres of diversity reported for Fynbos } \\
& \text { and Nama-Karoo }
\end{aligned}
$$

Total no. $\%$ of reported

Family and genus of taxa taxa in: Life form reported Fynbos Nama-

Karoo

\begin{tabular}{lllll}
\hline $\begin{array}{l}\text { Chenopodiaceae } \\
\text { Salsola }\end{array}$ & 24 & 58 & 63 & $\mathrm{Ch}, \mathrm{H}$ \\
$\begin{array}{c}\text { Asteraceae } \\
\text { Pteronia }\end{array}$ & 52 & 46 & 42 & $\mathrm{Ch}$
\end{tabular}

g. Large genus with centres of diversity reported for Nama-
Karoo and Succulent Karoo
Total no. $\%$ of reported
of taxa $\begin{gathered}\text { taxa in: } \\ \text { reported }\end{gathered}$
$\begin{gathered}\text { Nama- Succulent } \\ \text { Karoo Karoo }\end{gathered}$

$\begin{array}{llllll}\begin{array}{l}\text { Asteraceae } \\ \text { Eriocephalus }\end{array} & 19 & 63 & 58 & \mathrm{Ch}\end{array}$

\begin{tabular}{c}
\hline h. Large genus with centres of diversity reported for Nama- \\
Karoo and Desert \\
Total no. $\begin{array}{c}\text { \% of reported } \\
\text { of taxa } \\
\text { taxa in: } \\
\text { reported }\end{array} \begin{array}{c}\text { Nama- } \\
\text { Karoo }\end{array}$
\end{tabular}

Mesembryan themaceae

$\begin{array}{llllll}\text { Psilocaulon } & 19 & 47 & 32 & \mathrm{H}, \mathrm{T}\end{array}$

APPENDIX 3.-Large genera (10 taxa or more) with centres of diversity in three biomes. Life forms are abbreviated: P, phanerophyte; Ch, chamaephyte; H, hemicryptophyte; $\mathrm{C}_{\mathrm{r}}$, cryptophyte; $\mathrm{T}$, therophyte; $\mathrm{S}$, succulent

a. Large genera with centres of diversity reported for Savanna, Grassland and Fynbos

Total no. \% of reported

\begin{tabular}{|c|c|c|c|c|c|}
\hline $\begin{array}{l}\text { Fissidentaceae } \\
\text { Fissidens }\end{array}$ & 23 & 52 & 52 & 70 & H \\
\hline Celastraceae & & & & & \\
\hline Maytenus & 17 & 71 & 47 & 59 & $\mathrm{P}, \mathrm{Ch}$ \\
\hline Asteraceae & & & & & \\
\hline Conyza & 13 & 62 & 54 & 92 & $\mathrm{Ch}, \mathrm{H}, \mathrm{T}$ \\
\hline
\end{tabular}

$\begin{array}{llll}\text { Family and } & \text { of taxa } & \text { taxa in: } \\ \text { genus } & \text { reported Savan- Grass- Fyn- Life form }\end{array}$ na land bos; 


\begin{tabular}{|c|c|c|c|c|c|}
\hline \multicolumn{6}{|c|}{$\begin{array}{l}\text { b. Large genera with centres of diversity reported for Savanna, } \\
\text { Nama-Karoo and Desert }\end{array}$} \\
\hline $\begin{array}{l}\text { Family and } \\
\text { genus }\end{array}$ & $\begin{array}{c}\text { Total no. } \\
\text { of taxa } \\
\text { reported }\end{array}$ & $\begin{array}{c}\text { Savan- } \\
\text { na }\end{array}$ & $\begin{array}{l}\% \text { of repo } \\
\text { taxa in: } \\
\text { Nama } \\
\text { Karoo }\end{array}$ & $\begin{array}{l}\text { rted } \\
\text { Desert }\end{array}$ & Life form \\
\hline \multicolumn{6}{|l|}{ Poaceae } \\
\hline Stipagrostis & 34 & 50 & 65 & 68 & $\mathrm{H}$ \\
\hline \multicolumn{6}{|l|}{ Pedaliaceae } \\
\hline Sesamum & 14 & 71 & 50 & 50 & $\mathrm{H}, \mathrm{T}$ \\
\hline
\end{tabular}

c. Large genus with centres of diversity reported for Fynbos, Succulent Karoo and Nama-Karoo

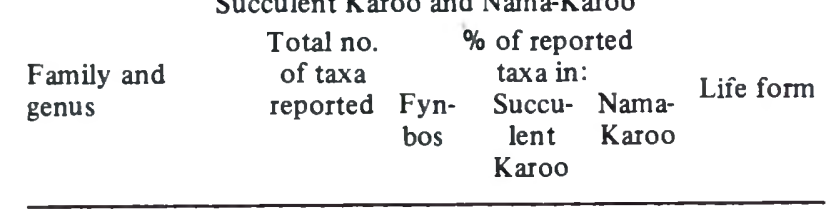

Zygophyllaceae

Zygophyllum

30

50

53

$57 \mathrm{Ch}$

\begin{tabular}{llllll}
\hline \multicolumn{1}{c}{ d. Large genus with centres of diversity reported for Fynbos, } \\
$\begin{array}{c}\text { Savanna and Nama-Karoo } \\
\text { Total no. } \\
\text { of taxa } \\
\text { reported }\end{array}$ & $\begin{array}{c}\text { Fyn- } \\
\text { Family and } \\
\text { taxa in: } \\
\text { genus }\end{array}$ & $\begin{array}{c}\text { Savan- } \\
\text { na }\end{array}$ & $\begin{array}{c}\text { Nama- } \\
\text { Karoo }\end{array}$ & Life form \\
\hline $\begin{array}{l}\text { Geraniaceae } \\
\text { Monsonia }\end{array}$ & 10 & 50 & 50 & 50 & $\mathrm{Ch}, \mathrm{H}, \mathrm{T}, \mathrm{S}$ \\
\hline
\end{tabular}

APPENDIX 4.- Large genera (10 taxa or more) with no apparent centre of diversity. Life forms are abbreviated: P, phanerophy te; Ch, chamaephyte; H, hemicryptophy te; $\mathrm{Cr}$, cryptophyte; T, therophyte; $\mathrm{S}$, succulent

\begin{tabular}{lll}
\hline Family and genus $\quad$ Total no. & $\begin{array}{l}\text { Vegetation type } \\
\text { with largest } \% \\
\text { of taxa }\end{array}$ \\
\hline
\end{tabular}

Liliaceae $s . l$.

Eriospermum

$$
\text { Aloe }
$$

Iridaceae

Brunsvigia

Mesembryanthemaceae

Ruschia

Fabaceae

Lessertia

Asclepiadaceae

Stapelia

Scrophulariaceae

Sutera

Campanulaceae

Wahlenbergia

Asteraceae

Berkheya

$\begin{array}{llll}39 & \text { Savanna } & 41 & \mathrm{Cr} \\ 98 & \text { Savanna } & 44 & \mathrm{Ch}, \mathrm{S} \\ 11 & \text { Fynbos } & 36 & \mathrm{Cr} \\ 55 & \text { Fynbos } & 40 & \mathrm{Ch}, \mathrm{S} \\ 33 & \text { Fynbos } & 42 & \mathrm{Ch}, \mathrm{H} \\ 27 & \text { Fynbos } & 44 & \mathrm{H}, \mathrm{S} \\ 72 & \text { Savanna } & 42 & \mathrm{Ch}, \mathrm{H}, \mathrm{T} \\ 46 & \text { Grassland } & 35 & \mathrm{H}, \mathrm{T} \\ 43 & \text { Grassland } & 47 & \mathrm{Ch}, \mathrm{H}\end{array}$

